\title{
IMPROVING SHEEP PRODUCTIVITY BY USING FRESH AND FROZEN SEMEN IN PALESTINE
}

\author{
H. A. M. Bast ${ }^{(1)}$, Omaima A. Khamiss ${ }^{(2)}$, E. A. Sabra ${ }^{(3)}$ \\ (1) Teacher in ministry of education in Palestine. \\ (2) Professor of Cell Culture and Virology, Animal Biotechnology Department, Genetic \\ Engineering \& Biotechnology Institute (GEBRI), University Sadat City. \\ (3) Lecturer of transgenic, Animal Biotechnology Department, Genetic Engineering \& \\ Biotechnology Institute (GEBRI), University of Sadat City.
}

Received: Apr. 5, 2021

Accepted: Jul. 26, 2021

\begin{abstract}
Livestock sector in Palestine is an important one, contributing up to $46 \%$ of total agricultural income. The backbone of this sector is sheep and goats (small ruminants), dairy cattle and poultry. This study aimed to improve sheep productivity and develop long term breeding program for sheep breeds and crosses under field conditions in Palestine under different production systems.
\end{abstract}

This experimental study included 169 ram sheep. The single semen collected from each ram was divided into four parts and extended using four extenders: milk, TRIS, TEST, and CJ-2 (diluted to 600 million sperm/ ml) and loaded into $0.25 \mathrm{ml}$ straws for storage at 4 and $15^{\circ} \mathrm{C}$. Most of the computer assisted sperm analyze the motility parameters were higher after extension and storage at 4 compared with $15^{\circ} \mathrm{C}(P<0.05)$. Ram semen stored using milk or TRIS based extenders at $4^{\circ} \mathrm{C}$. They are also retained similar sperm motility parameters but both were higher compared with TEST or CJ-2 extenders after storage for up to 3 days $(P<0.05)$. Results showed that ram race AF recorded $(151)$ with ratio $89.3 \%$ while the race IA recorded (18) with ratio 10.7\%. The entire169 ram from Ministry of Agriculture had pregnancy check after 41 days of semen insemination and the result was $100 \%$ pregnancy happened. Date of birth was after 5 months of semen insemination. On the other hand, average number of births was1.5. The greatest numbers of births (89) were belonged to females which represent $52.7 \%$ of the total births while the male births were 80 with ratio $47.3 \%$. The net average weight of a newborn was about $5.6 \pm 1.4 \mathrm{~kg}$. The weights of births were gradually increased and the average weight of a newborn at weaning was about $19.5 \pm 2.3 \mathrm{~kg}$. The average amount of milk in the first stage of milking was about $1.7 \pm 0.29 \mathrm{~L}$ while in the second stage of milking was about $1.6 \pm 0.29 \mathrm{~L}$ and finally in the third stage of milking was about $1.46 \pm 0.28 \mathrm{~L}$. In conclusion, the ram race AF recorded with higher ratio than the race IA. The average weight of a newborn at weaning was about $19.5 \pm 2.3 \mathrm{~kg}$. Finally the third stage was reported to be with the least value of all the stages of milking.

Key words: Sheep productivity, fresh and frozen semen, insemination Palestine.

\section{INTRODUCTION}

Palestine located in the Near East Region. Small ruminants play an important role on the economical, ecological, environmental and cultural levels (Zarkawi et al., 1999).

It contributes in the conversion of thousands of marginal hectares into high quality protein and account for $\mathbf{3 0 - 4 0} \%$ of agricultural output value in the nearby eastern countries (Blacksburg, 1988).

It is an important socio-economic activity in Palestine and plays a very essential role for the livelihood. Total number of sheep was 639 in the West 
Bank city during the agricultural year 2006/2007, 159 with small herd size which makes it difficult to improve productivity of animals (PCBS, 2011).

The main sheep breed in Palestine is; local Awassi. The second breed is Assaf (crossbreeding between improved Awassi and East-Friesian). The new Awassi strain called Afec Awassi (crossbreeding between the Booroola Marino and the improved Awassi), was introduced (Gootwine, and Pollott, 2000).

In spite of its importance, farmers have not improved the efficient breeding system at farm level. As well as recording of performance data of sheep genotypes kept by Palestian farmers are scarcely reported. Absence of organized breeding programs by the government creates useless results. Thus, it is difficult to improve sheep performance under such circumstances (Gootwine, and Pollott, 2000).

We believe that we can gain benefits from the results of the small ruminant regional programs, and other data about live stock in Palestine to develop practical breeding and selection programs to improve meat and milk production for sheep breeds and crosses in Palestine (PCBS, 2011).

The study aimed to improve meat and milk production for sheep breeds and crosses in Palestine, by selecting the efficient and good rams that have good semen quality using recent techniques.

\section{MATERIALS AND METHODS Study design:}

The West Bank city consists of four agro-ecological zones; semi costal, central high lands, eastern slopes, and Jordan valley.

Mature rams were clinically healthy. All rams had access to water, and mineral salt, and $0.5 \mathrm{~kg} / \mathrm{day}$ of corn/soybean meal (17\% CP, $82 \%$ TDN on DM basis) per ram.

Semen was collected by electroejaculation into $15 \mathrm{ml}$ polystyrene tubes, screw capped and placed immediately into thermo-flask (Lab-line Instruments Inc., Melrose Park, IL) containing water maintained at $35^{\circ} \mathrm{C}$.

Semen samples were transported to the laboratory for investigation. Evaluation of fresh semen was done by computer assisted sperm analysis (CASA; Hamilton-Thorne, IVOS, Beverly MA) with 12 TOX IVOS software. All semen samples were evaluated within 2 hours post collection.

Sperm motility parameters were analyzed using the default analysis settings recommended by manufacturer for ram semen. Semen samples were diluted in CJ-2 extender without egg yolk at 1:100 (semen: extender ratio). About $3.5 \mu \mathrm{l}$ of diluted sample was placed in disposable $20 \mu \mathrm{m}$ deep, 2-chambered IVOS slide (Cytonix, Beltsville, MD).

At least four fields were scanned, with 30 video frames captured per field at a frame rate of $60 \mathrm{~Hz}$.

A minimum of 400 sperm cells were counted in each sample. Variables measured with CASA were motility (\%), progressive motility (\%), track speed (VCL, $\mu \mathrm{m} / \mathrm{sec}$ ), path velocity (VAP, $\mu \mathrm{m} / \mathrm{sec}$ ), progressive velocity (VSL, $\mu \mathrm{m} / \mathrm{sec}$ ), beat frequency (BCF, $\mathrm{MHz}$ ), lateral amplitude $(A L H, \mu m)$, linearity (LIN, \%) and straightness.

The collected data was revised, coded, tabulated and introduced to a computerized system using Statistical package for Social Science by SPSS program version 23. Data was presented and proper statistical analysis was done according to the type of data obtained for each parameter.

The mean, standard deviation ( \pm SD) and range for parametric numerical data, 
while median and interquartile range (IQR) for non-parametric numerical data were obtained and analyzed. Frequency and percentage of non-numerical data were also analyzed. ANOVA test of significance was used when comparing between means of more than two groups. Chi-Square test was used to examine the relationship between two qualitative variables. Fisher's exact test was used to examine the relationship between two qualitative variables when the expected count is less than 5 in more than $20 \%$ of cells. The $P$ value was significant $(S)$ at $(P<0.05)$

\section{RESULTS}

Table 1 showing that Tobas country recorded 809 total number of samples which divided into 11.7, 83.3 and $5.0 \%$ El-Hadedya, Bardalah and El- Ras respectively as shown in Table (1). Ewe race varied between $X B$ which represented $(84 \%)$ and $A F$ which represented (16\%). On the other hand, lambing number 3 had the largest percentage (49.1) while lambing number 6 had the lowest percentage (7.1\%), Table (1).
Fourteen farmers participated in this study. The contribution of these small holders ranged between 4.2 to $11.8 \%$. Average days from sponge date to hormone date were 14 days. Furthermore, the average days from hormonal date to insemination date was only two days and average days from sponge date to insemination date was 16 days.

Table (2) illustrating that the ram race AF recorded (151) with ratio $89.3 \%$ while the race IA recorded (18) with ratio $10.7 \%$. The entire 169 ram from MOA had pregnancy check after $\mathbf{4 1}$ days of semen insemination and the result was $100 \%$ pregnancy was happened.

The birth date occurred after 5 months of injection. Alternatively, the average number of births was 1.5 (1). The greatest numbers of births (89) were belonged to females which represented $52.7 \%$ of the total births while the male births were 80 with ratio $47.3 \%$.

The net average weight of a newborn was about $5.6 \pm 1.4 \mathrm{~kg}$, the weights of births were progressively increased. The average weight of a newborn at weaning was about $19.5 \pm 2.3 \mathrm{~kg}$.

Table (1): Descriptive data about sample $(n=809)$.

\begin{tabular}{|l|c|c|}
\hline Variables & Number & Percentage(\%) \\
\hline Regions & 809 & 100 \\
\hline Tobas & 95 & 11.7 \\
\hline Aggregate & 974 & 83.3 \\
\hline El-Hadedya & 40 & 5 \\
Bardalah & & \\
El-Ras $\$$ & 679 & 84 \\
\hline Ewe race & 130 & 16 \\
XB & & 11.9 \\
Lambing number & 95 & 49.1 \\
\hline 2 & 397 & 21.3 \\
4 & 172 & 10.7 \\
5 & 87 & 7.2 \\
6 & 58 & \\
\hline
\end{tabular}

Table (2): Summary of insemination outcome $(n=809)$. 
H. A. M. Bast, et al.,

\begin{tabular}{|c|c|c|c|c|}
\hline Variable & $\begin{array}{l}\text { Fresh } \\
(n=169)\end{array}$ & $\begin{array}{l}\text { Frozen } \\
(\mathrm{n}=640)\end{array}$ & $\begin{array}{l}\text { Test } \\
\text { value }\end{array}$ & P-value \\
\hline $\begin{array}{l}\text { Belly No } \\
+2 \\
+6 \\
\$ 7 \\
+10 \\
+11 \\
+13 \\
+5075 \\
+507\end{array}$ & $\begin{array}{c}22(13 \%) \\
10(5.9 \%) \\
11(6.5 \%) \\
68(40.3 \%) \\
13(7.7 \%) \\
20(11.8 \%) \\
8(4.7 \%) \\
18(10.1 \%)\end{array}$ & $\begin{array}{c}66(10.3 \%) \\
30(4.7 \%) \\
41(6.4 \%) \\
248(38.8 \%) \\
43(6.7 \%) \\
68(10.6 \%) \\
30(4.7 \%) \\
114(17.8 \%)\end{array}$ & 1.827 & $0.716^{2}$ \\
\hline $\begin{array}{c}\text { The sheep`s breed } \\
\quad \text { AF } \\
+ \text { IA }\end{array}$ & $\begin{array}{l}151(89.3 \%) \\
18(10.7 \%)\end{array}$ & $\begin{array}{l}563(88 \%) \\
77(12 \%)\end{array}$ & 1.98 & $0.632^{2}$ \\
\hline $\begin{array}{c}\text { The source of the sheep } \\
\text { MOA }\end{array}$ & $169(100 \%)$ & $640(100 \%)$ & 0.00 & $1.00^{2}$ \\
\hline $\begin{array}{l}\text { Date of pregnancy test } \\
\text { after injection(Day) }\end{array}$ & 41 & 41 & 0.00 & $1.00^{2}$ \\
\hline Pregnancy occurs & $169(100 \%)$ & $388(60.6 \%)$ & 0.928 & $<0.001^{*^{2}}$ \\
\hline $\begin{array}{c}\text { Date of birth after the } \\
\text { injection }\end{array}$ & 5 & 5 & 0.00 & $1.00^{2}$ \\
\hline $\begin{array}{c}\text { Number of births } \\
1 \\
2 \\
3\end{array}$ & $\begin{array}{c}102(60.4 \%) \\
55(32.5 \%) \\
12(7.1 \%)\end{array}$ & $\begin{array}{c}284(44.4 \%) \\
101(15.8 \%) \\
3(0.4 \%)\end{array}$ & 10.52 & $0.019^{*^{1}}$ \\
\hline Average number of births & $1.5(1)$ & $1(1)$ & 0.00 & $1.00^{1}$ \\
\hline $\begin{array}{c}\text { Kind Births } \\
+ \text { Male } \\
+ \text { Female }\end{array}$ & $\begin{array}{l}80(47.3 \%) \\
89(52.7 \%)\end{array}$ & $\begin{array}{c}97(25 \%) \\
291(75 \%)\end{array}$ & 8.221 & $0.032^{\star 1}$ \\
\hline Average birth weight & $5.6 \pm 1.4$ & $5.2 \pm 0.9$ & 2.357 & $0.182^{2}$ \\
\hline $\begin{array}{l}\text { Average weight of a baby } \\
\text { at weaning }\end{array}$ & $19.5 \pm 2.3$ & $17.4 \pm 1.5$ & 4.224 & $0.048^{\star^{2}}$ \\
\hline $\begin{array}{l}\text { The average amount of } \\
\text { milk in the first ring. }\end{array}$ & $1.7 \pm 0.29$ & $1.7 \pm 0.17$ & 0.928 & $0.926^{2}$ \\
\hline $\begin{array}{l}\text { The average amount of } \\
\text { milk in the second ring. }\end{array}$ & $1.6 \pm 0.29$ & $1.5 \pm 0.21$ & 3.221 & $0.082^{2}$ \\
\hline $\begin{array}{l}\text { The average amount of } \\
\text { milk in the ring. }\end{array}$ & $1.46 \pm 0.28$ & $1.44 \pm 0.222$ & 1.092 & $0.113^{2}$ \\
\hline
\end{tabular}

1. Chi square test used. 2. Independent t test used.

*Statistically significant as $\mathrm{p}<0.05$.

The average amount of milk in the first stage of milking was about $1.7 \pm 0.29 \mathrm{~L}$, while the average amount of milk in the second stage of milking was about $1.6 \pm 0.29 \mathrm{~L}$. Finally, the average amount of milk in the third stage of milking was about $1.46 \pm 0.28 \mathrm{~L}$.

DISCUSSION
Sheep are considered a precious livestock species as a result of their ability to convert forages, as well as feedstuffs not suitable for human consumption, into meat and milk that are important sources of human dietary protein (Elshazly and Youngs, 2019). 
Alvares et al. (2015) stated that artificial insemination (Al) technique is an assisted reproduction technology and consists in the application of a dose of semen into the female reproductive tract by means of instruments. In combination with other technologies such as induction/synchronization of estrus and ovulation, Al can add genetic value to livestock by spreading the use of males of high productive characteristics.

Moreover, Gibbons et al. (2019) indicated that in some countries the artificial insemination had a great development and has served as a fundamental tool for genetic improvement in sheep.

Epstein, (1987) reported that the name of the "Awassi" is attributed to the ElAwas tribe located between the Tigris and Euphrates rivers. Fat-tailed sheep have been bred in this area for at least 5000 years, and physically and functionally, the Awassi seems to be very close to the prototype from which the fattailed sheep of Asia, Africa and Europe are derived.

On the other hand, Palestinian Central Bureau of Statistics reported that in 2010, Awassi represented $54.5 \%$ of the total West Bank sheep population while Assaf and Awassi x Assaf accounted for $45 \%$, (PCBS, 2011).

Ahmed and Abdallah, (2013) reported that the more recent investigation by the Ministry of Agriculture (MoA, 2013, unpublished) found that Awassi only comprised about $20 \%$ of the total sheep population in the West Bank.

Fourteen farmers participated with in this study with different reported values as largest number (20) recorded with Youssief Hussien, Asmer besharat and the smallest number recorded with Menyezel Hassen, Eqab Rabayaah had the smallest number (7).
In accordance with the above mentioned results Ahmed and Abdallah (2013) study the collected data between 2003 and 2010 from 21 farms covering five locations in southern West Bank (Dora, Hebron, Bethlehem, Jerusalem, and Ramallah) and three locations in northern West Bank city (Nablus, Qalqiliya, and Jenin) and the results showed significant differences $(P<0.05)$ in performance and within breeds in different locations.

It was previously documented that ewes were lambing more frequently per year. The most accelerated lambing systems commonly used are three lamb crops per ewe every two years (Gül and Keskin, 2010).

Gabr et al. (2016) reported that intensive reproductive management can reduce maintenance costs of breeding stock per offspring reared, will often increase net return and will provide a more uniform supply of lamb throughout the year.

Moreover, Abdullah et al. (2002) who study protocols for estrus synchronization in Awassi ewes under arid conditions informed that estrus synchronization of ewes has been accomplished using several methods with various degrees of success.

Synchrony of estrus following the most traditional methods is not precisely enough to enhance first-cycle pregnancy and lambing rates and the commonly used protocol was based on the use of intra-vaginal progestogen sponges inserted for 12 to 14 days followed by eCG/PMSG at sponge removal and ram introduction for mating (Husein and Hamit, 2005).

The average days from sponge date to hormone date was 14 days as documented previously. On the other hand, average days from hormone date to insemination date was only two days 
and average days from sponge date to insemination date was 16 days.

In this concern, Ucar et al. (2005) reported that all the ewes were treated by $30 \mathrm{mg}$ Chronolone-impregnated intravaginal sponges for 14 days, their results revealed that lambing rates and litter sizes were recorded following the $150 \pm 5$ days of inseminations (handmating) and results showed that oestrus period was significantly prolonged $(P<$ 0.05 ) in Group I.

On the other hand, Abdel-Khalek, et al. (2014) studies estrus synchronization in ewes using sponges with PMSG or rams effect with or without progesterone injection. Their results indicated that the progestagen-based intravaginal sponge treatments are the most appropriate hormonal technique for sheep fertility control. In the cycle of the females, it acts by suppressing the pre - ovulatory pituitary release of gonadotropins and, therefore, follicular growth and ovulation.

The greatest numbers of births in case of fresh semen were belonged to females while the greatest numbers of births in case of frozen semen were belonged to females which are higher than males with P-value $0.032 * 1$. In the same line with our current results Paulenz et al. (2007) reported that vaginal insemination with $200 \times 106$ spermatozoa resulted in 25days non-return rates of $63.2,59.6$, and $62.5 \%$ (overall $61.8 \%$ ), respectively, and lambing rates of $56.8,55.0$, and $59.2 \%$ (overall $\mathbf{5 7 . 0 \%}$ ), respectively.

The net average weight of a newborn was about $5.6 \pm 1.4 \mathrm{~kg}$ for fresh insemination and $5.2 \pm 0.9 \mathrm{~kg}$ for frozen insemination with $P$-value 0.1822 , the weights of births were gradually increased and the average weight of a newborn at weaning was about $19.5 \pm 2.3$ $\mathrm{kg}$ for fresh insemination and $17.4 \pm 1.5 \mathrm{~kg}$ for frozen insemination with $P$-value $0.048 * 2$.
As it was reported with Haile et al. (2019) the values for weaning weight (WW) and pre-weaning weight gain (WG) were negative, even though they were significant $(P<0.05)$. These estimates were positive and significant $(P<0.05)$ for all reproduction and milk traits, except for litter weight at birth (LWB).

In agreement of the above mentioned results, Gursoy et al. (1995) studies on Awassi sheep showed slightly higher pre-weaning daily gain observed for the offspring of the Israeli rams were not found to be significant also birth weight was seen to have a moderate genetic correlation with weaning weight $(61.6 \%)$ and preweaning daily gain (49.5\%).

In this concern, Haile et al. (2017) reported that weight differences (birth weight, weaning weight, litter weight at birth and litter weight at weaning) between male and female were significant $(p<0.01)$ and in all cases, males were heavier weight than females.

Bencini and Pulina (1997) reported that the factors affecting the quality of the milk of sheep such as the genotype of the sheep are difficult to control, but others are environmental factors, such as the nutrition and management of the milking flock, and can be manipulated by the farmer to produce high quality milk. To obtain high quality milk, ewes must be milked out regularly and completely, which implies adopting appropriate milking routines and milking equipment and it is also important that the ewes are healthy and receive adequate diets.

On the other hand, Rummel et al. (2005) informed that due to the high milk production and adaptability to Mediterranean conditions, Improved Awassi and Assaf sheep have been exported from Israel to several countries including the Palestinian Authority. Therefore the prolificacy of Improved Awassi and Assaf ewes is relatively low 
to moderate: 1.28 and 1.60 lambs born/lambing, respectively (Pollott and Gootwine, 2004).

In the results of our current study, the average amount of milk in the first stage of milking was almost equal in fresh insemination and in frozen insemination. However, the average amount of milk in the second stage of milking was slight higher in fresh insemination than that of frozen and finally the average amount of milk in the third stage of milking was about was almost equal in fresh insemination and in frozen insemination. Accordingly, Ahmed and Abdallah (2013) reported that milk production was highest for Awassi $x$ Assaf in Nablus and Jenin (least-squares means of $330.6 \mathrm{~kg}$ and $267.6 \mathrm{~kg}$ for total milk yield in $150 \mathrm{~d}$ of lactation, respectively) and Assaf in Jenin $(268.1 \mathrm{~kg})$, and was lowest for Awassi in Jerusalem (124.6 kg).

\section{Conclusion}

In conclusion, the artificial insemination (Al) technique is an assisted reproduction technology. Average days from sponge date to hormone date were 14 days and that from hormonal date to insemination date was only two days. However average days from sponge date to insemination date was 16 days. The ram race $A F$ recorded with higher ratio than the race IA. The greatest numbers of births were belonged to females. The net average weight of a newborn was about $5.6 \pm 1.4 \mathrm{~kg}$. The weights of births were gradually enlarged and the average weight of a newborn at weaning was about $19.5 \pm 2.3 \mathrm{~kg}$. The second stage of milking was reported to be of lesser value than first stage but it was a higher value than the third stage of milking. Finally the third stage was reported to be with the least value of all the stages of milking.

\section{REFERENCES}

Abdel-Khalek, A.E., W.A. Khalil, B.E. ElSaidy and A. I. Youssif (2014). Estrus synchronization in ewes using sponges with PMSG or rams effect with or without progesterone injection. J. Animal and Poultry Prod., Mansoura Univ., 5 (4): 173 - 185.

Abdullah, A. Y., M. Q. Husein and R. T. Kridli (2002). Protocols for estrus synchronization in Awassi ewes under arid conditions. Asian- Aust. J. Anim. Sci., (15): 957-962.

Ahmed, M. and J. Abdallah (2013). Comparison of milk yield and reproductive performance of sheep breeds in the West Bank, Palestine. A Najah Univ. J. Res. 27: 11-128.

Alvares, C.T.G., J.F. Cruz and M.L. Ferreira (2015). Artificial insemination techniques and pathophysiological implications in Maringá sheep. Pub vet., 9(5): 220-231.

Bencini, R. and G. Pulina (1997). The quality of sheep milk: a review. Australian Journal of Experimental Agriculture 37(4): 485 - 504.

Blacksburg, V.A. (1988). Recommended minimum standards for artificial insemination training. National Association of Animal Breeders. Columbia, MO Semen-handle with care.

Elshazly, A.G. and C.R. Youngs (2019). Feasibility of utilizing advanced reproductive technologies for sheep breeding in Egypt. Part 1. Genetic and nutritional resources. Egyptian Journal of Sheep \& Goat Sciences, 14 (1): 39- 52.

Epstein, H. (1987). Small ruminants in the Near East; Food and Agriculture Organization of the United Nations; pp.29-32.

Gabr, A.A., N.A. Shalaby and M.E. Ahmed (2016). Effect of ewe born type, growth rate and weight at conception on the 
ewe subsequent productivity of Rahmani Sheep. Asian J. Anim. Vet. Advan., 11:732- 736.

Gibbons, A. E., J. Fernandez, M. M. Bruno-Galarraga, M. V. Spinelli and $M$. I. Cueto (2019). Technical recommendations for artificial insemination in sheep. Anim Reprod., 16(4): 803-809.

Gootwine, E. and G.E. Pollott (2000). Factors affecting milk production in improved Awassi dairy ewes, Animal Sci. 71: 607- 615.

Gül, S. and M. Keskin (2010). Reproductive characteristics of Awassi ewes under Cornell alternate month accelerated lambing system. Italian J. Anim. Sci., 9: e49.

Gursoy, O., K. Kirk, Z. Cebeci and G.E. Pollot (1995). Genetic evaluation of growth performance in Awassi sheep. In: Gabiña D. (ed.). Strategies for sheep and goat breeding. Zaragoza: CIHEAM,. p. 193- 201 (Cahiers Options Méditerranéennes; n. 11).

Haile, A., M. Hilali, H. Hassen, R. Lobo and B. Rischkowsky (2019). Estimates of genetic parameters and genetic trends for growth, reproduction, milk production and milk composition traits of Awassi sheep. Animal, 13(2):240-247.

Haile, A., M. Hilali, H. Hassen, M. Rekik, R. Lobo, N. B. M. Tibbo, J. M. Mwacharo and B. Rischkowsky (2017). Evaluation of Awassi sheep genotypes for growth, milk production and milk composition. Journal of Experimental Biology and Agricultural Sciences, 5(Spl-1- SAFSAW)
Husein, T. and Y. Hamit (2005). Synchronization of estrous in Hamdani ewes: the use of different PMSG doses. Bull. Vet. Inst. Pulawy., (49): 311-314.

Paulenz, H., T. Adnøy and L. Söderquist (2007). Comparison of fertility results after vaginal insemination using different thawing procedures and packages for frozen ram semen. Acta veterinaria Scandinavica, 49(1): 26.

PCBS: Palestinian Central Bureau of Statistics (2011): Agricultural Census 2010. Final Results- Palestinian Territories. Ramallah, Palestine.

Pollott, G. E. and E. Gootwine (2004). Reproductive performance and milk production of Assaf sheep in an intensive management system, J. Dairy Sci. 87: 3690-3703.

Rummel, T. A.V. Zarate and Gootwine, E. (2005): The Worldwide Gene Flow of the Improved Awassi and Assaf Sheep Breeds from Israel, Verlag Ulrich E. Grauer, Beuren, Stuttgart (2005) pp. 51.

Ucar, O., M. Kaya, S. Yildiz, F. Onder, M. Cenesiz and M. Uzun (2005). Effect of progestagen/PMSG treatment for oestrus synchronization of Tuj ewes to be bred after the natural breeding season. Acta Vet. Brno., 74: 385-393.

Zarkawi, M., Al-Merestani M.R. and M.F. Wardeh (1999). Induction of synchronized estrous and early pregnancy diagnosis in Syrian Awassi ewes outside the breeding season. Small Rumin. Res., 33: 99-102. 
تحسين إنتاجية الضأن عن طريق استخدام نطف طازجة ومجمدة في فلسطين

حكم أحمد مصطفى بسط|")، أميمية أحمد خميس(†)، إبر اهيم عبدالمحسن صبره(")،

(1) (1) مدرس فى وزارة التربية و التعليم فى فلسطين

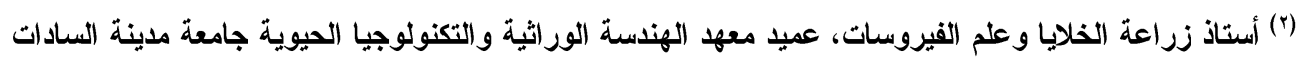

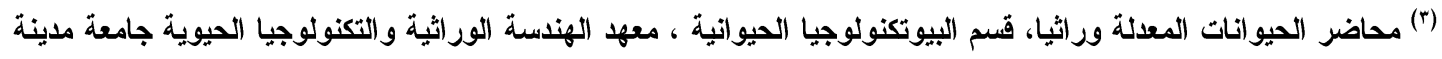

السادات

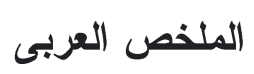

الخلفية: يعتبر قطاع الثروة الحيوانية في فلسطين قطاعًا مهمًا ، حيث يساهم بنسبة تصل إلى جـ ٪ من إجمالي الاخل

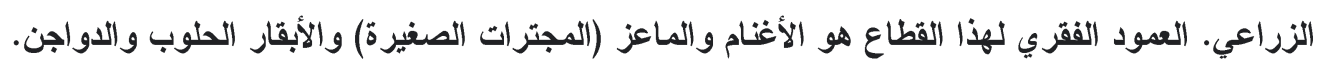
الهُف: هدفت هذه الدراسة إلى تحسين إنتاجية الأغنام وتطوير برنامج تربية طويل المدى لسلالات الأغنام والصلبان تحت الظروف الحقلية في فلسطين وأنظمة الإتتاج المختلفة.

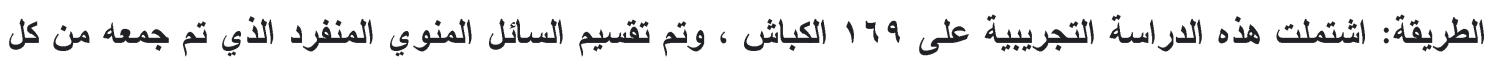

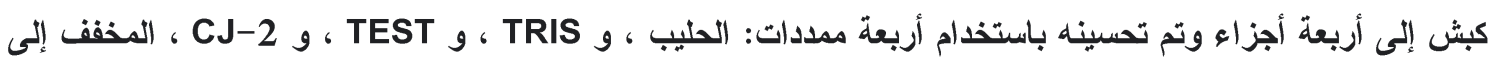

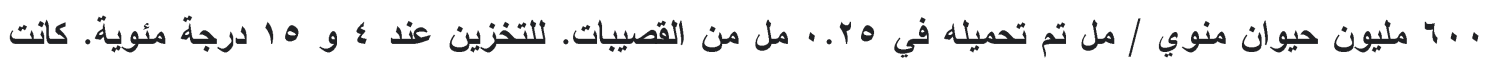

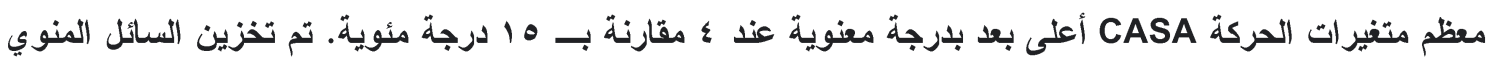

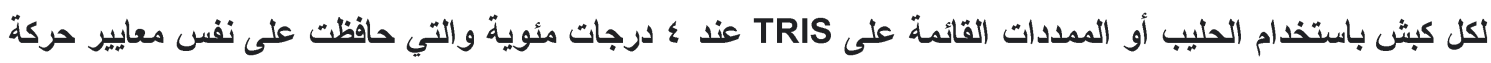

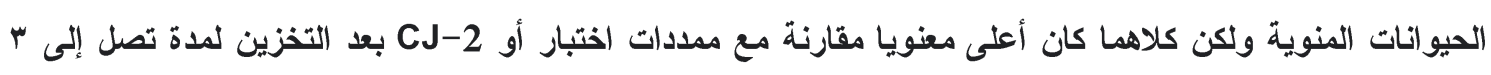

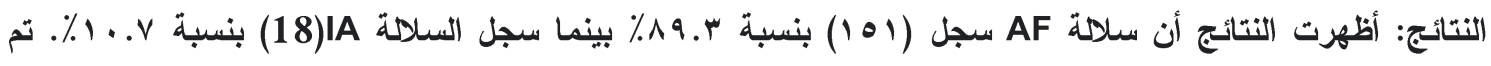

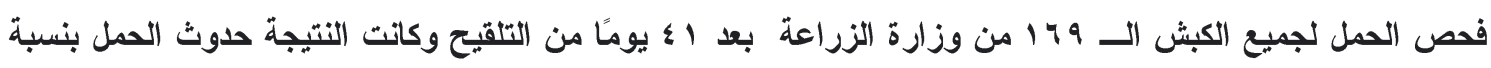

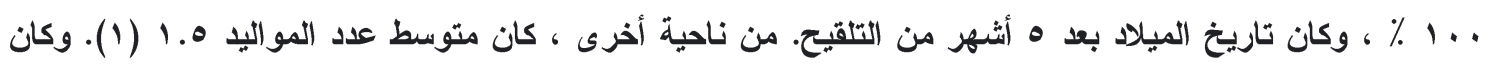

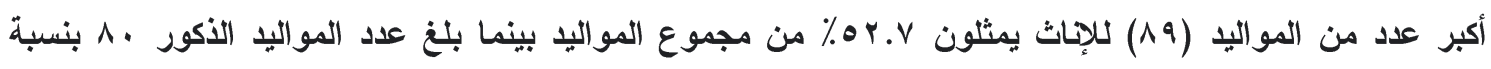

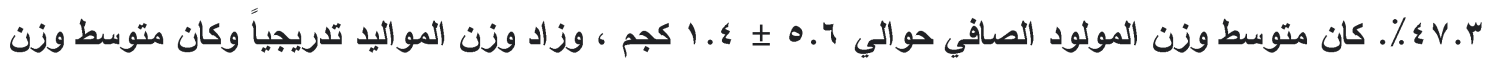

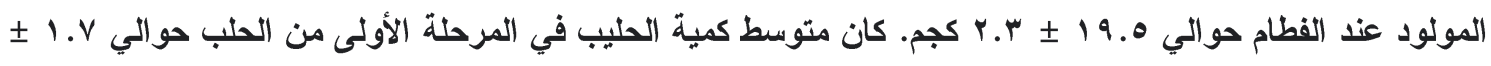

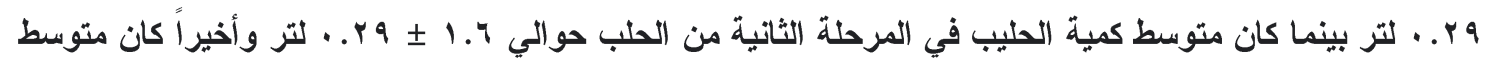

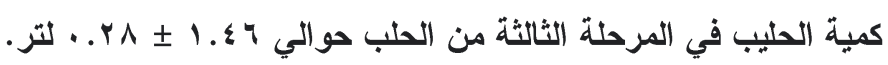

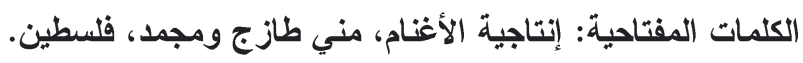

أسماء السادة المحكمين أ.د/ جمال عاثنور كلية الزراعة - جامعة القاهرة 
H. A. M. Bast, et al.,

أ.د/ عصمت بكرى كلية الزر اعة - جامعة عين شمس 